\title{
INTELIGENČNí A VÝVOJOVÁ ŠKÁLA \\ PRO DĚTI VE VĚKU 5-10 LET (IDS) \\ Recenze metody
}

Autor ReCEnZE: PhDr. Lenka KRejČová, Ph.D. ${ }^{1,2}$

\begin{tabular}{|c|l|}
\hline \multicolumn{1}{|c|}{ datum vzniku recenze: } & 11.10 .2013 \\
\hline 1.1 název nástroje: & Inteligenční a vývojová škála pro děti ve věku 5-10 let \\
\hline zkrácený název: & IDS \\
\hline 1.2 původní název: & Intelligence and Development Scales \\
\hline 1.4 autoři původního testu: & $\begin{array}{l}\text { Alexander Grob, Christine S. Mexer, } \\
\text { Priska Hagmann-von Arx }\end{array}$ \\
\hline 1.3 autoři lokální adaptace: & $\begin{array}{l}\text { Dana Krejčířová, Tomáš Urbánek, Jan Širůček, } \\
\text { Michal Jabưrek }\end{array}$ \\
\hline 1.7 lokální distributor: & Hogrefe - Testcentrum \\
\hline $1.9 .1 / 1.9 .2$ datum vydání: & 2013 \\
\hline
\end{tabular}

V současné poradenské i klinické psychologické praxi je při diagnostice kognitivních schopností dětí zřejmě nejčastěji užívaným nástrojem Wechslerova inteligenční škála pro děti (WISC-III). Př́ležitostně je alternována dalšími diagnostickými metodami (např. WJ-IE II, SON-R 21/2-7, K-ABC), které ale všechny mají určité limity, at' už se jedná o dostupnost metody, cílovou skupinu nebo kvalitu standardizace. Nejčastěji užívaný WISC-III začíná zastarávat (v anglicky hovořícím světě je již řadu let používána verze WISC-IV), a to jak z hlediska moderních diagnostických trendů (ve smyslu klinického zhodnocení kognice i ve smyslu standardizačních postupů), tak zhlediska položek v jednotlivých subtestech (které dítě dnes pozná, že telefonu chybí šňůra u sluchátka, či si pamatuje užívání padesátníků). Metoda IDS tedy jednoznačně zaplňuje mezeru v nabídce diagnostických nástrojů zaměřených na kognitivní funkce. Jen škoda, že horní

\footnotetext{
${ }^{1}$ Katedra psychologie, Filozofická fakulta UK, nám. Jana Palacha 2, 11638 Praha 1

2 DYS-centrum® Praha, z.ú., Stejskalova 9, 18000 Praha 8
} 
věková hranice činí deset let - to je ovšem charakteristika původní metody, na níž bylo zřejmě těžké při české lokalizaci něco měnit.

Metoda IDS je v porovnání s výše zmíněnými diagnostickými nástroji v několika směrech unikátní. Její původní verze vznikla v německy hovořících zemích Evropy, jedná se tedy o jeden z mála nástrojů, který není převzat z Ameriky. Východiskem pro vznik metody byl Inteligenční test Kramerové, který čerpal inspiraci pro svůj vznik v tradičním pojetí inteligence Bineta a Simona. V jejich přístupu je kognice vnímána spíše jako flexibilní proces, který se proměňuje v interakci s okolím, s vychovateli a učiteli, nikoli jako daný stav. Lze konstatovat, že ve Wechslerových škálách v tomto smyslu došlo k určité redukci tradičního pojetí inteligence podle zmíněných autorů. Tento návrat ke kořenům je velmi př́ijemný z hlediska další poradenské i klinické práce s dětskými klienty, nebot' nabízí mnohem více podnětů pro vhodnou intervenci a/nebo terapii. Veškerá východiska jsou v manuálu metody velmi pečlivě zpracována za využití značného množství relevantní literatury. První část manuálu lze pokládat za stručnou učebnici kognitivního vývoje dětí a rozhodně čtenářům poskytne množství důležitých údajů.

Metoda IDS vyžaduje individuální administraci, která trvá 1,5-2 hodiny, což lze pokládat za určitým způsobem limitující, nebot' pro menší děti může být délka vyšetření vyčerpávající. Na druhou stranu všechny komplexní diagnostické baterie tohoto typu kladou obdobné časové nároky na práci s klienty. V tomto směru naopak stojí za pozornost výtěžnost celé baterie, nebot' jednotlivé subtesty nabízejí široké spektrum informací, jež může diagnostik o klientovi získat. Mimo to v porovnání s některými dalšími diagnostickými nástroji využívá IDS velmi atraktivní podnětový materiál, s nímž proband různě manipuluje a při práci je dosti činorodý, což bezpochyby vede k jeho větší aktivizaci a délka vyšetření tak nemusí být kontraindikací k využití metody.

Dvacet jedna subtestů metody IDS, utříděných do dvanácti škál, je rozděleno velmi zajímavým způsobem do dvou hlavních oblastí. První mapuje celkový kognitivní vývoj, vycházející spíše s pojetí fluidní inteligence. Druhá sleduje celkový vývoj, jenž se zaměřuje na úroveň psychomotoriky, řečových dovedností, matematických dovedností, sociálně-emočních kompetencí a výkonovou motivaci probanda. Jinými slovy, IDS zachycuje nesmírně široké spektrum charakteristik jedince, které můžeme za využití jedné testové baterie sledovat. Za pozornost rozhodně stojí například zařazení subtestů zaměřených na sociální a emocionální rozvoj, které nebývají běžnou součástí diagnostických baterií věnovaných kognitivním schopnostem. Stejně tak je pozoruhodná škála motivace, která nepracuje př́mo s výkony probanda, ale jedná se o hodnotící škálu, pro niž jsou využity údaje $\mathrm{z}$ celého vyšetření pozorované a zachycené diagnostikem. Při adaptaci české verze metody byly navíc vytvořeny dva nové subtesty, které velmi efektivně rozšiřují oblast kognitivního vývoje ve sledování jeho verbální složky. Jednoznačně lze říci, že každý subtest, resp. každá škála přináší bohaté využití a představuje nosný zdroj diagnosticky cenných informací. Pro proces diagnostiky je mimo to velmi zajímavá aktivita diagnostika, od něhož je vyžadována značná kreativita a flexibilita (tento nástroj rozhodně neumožní, aby metodu administrovala jedna osoba 
a druhá osoba na základě získaných dat interpretovala výsledky). Na diagnostika jsou kladeny značné nároky z hlediska porozumění východiskům jednotlivých škál, resp. principům kognitivních i osobnostních charakteristik, které škály sledují. Zatímco dítě je diagnostikou zatěžováno relativně méně (spíše plní relativně rychlé a atraktivní úkoly se zajímavým materiálem), diagnostik musí být stále ve střehu, věnovat pozornost všemožným projevům dítěte a přizpůsobovat jim práci s ním. Tento aspekt vyšetření lze pokládat za nesmírně cenný, nebot' nabízí obsáhlé množství informací a podnětů pro další edukační praxi.

Česká lokalizace metody bezpochyby splnila všechna základní kritéria kladená na proces adaptace diagnostických metod podobného formátu. Pro české normy byl využit soubor bezmála dvou tisíc dětí vuvedené věkové skupině napříc celou republikou. Pro zpřesnění norem byl dokonce ve škále sociálně-emočních kompetencí realizován dodatečný sběr dat po její drobné úpravě. Stejně tak byly v průběhu standardizace na základě statistických dat precizovány nově vzniklé subtesty, aby v maximální možné míre rozšriřily výtěžnost původní baterie.

Normy vznikly na základě vyšetření běžné intaktní populace. Reliabilita a validita nástroje byla prověřena základními statistickými postupy. Bohužel časové možnosti v průběhu lokalizace metody neumožnily obsáhlejší měření pro obohacení údajů o reliabilitě a validitě. Některá data tohoto typu byla do manuálu převzata z původní německé verze. Základní údaje jsou ovšem $\mathrm{k}$ dispozici a tento nedostatek může být podnětem pro akademiky, kteří by mohli v rámci svých výzkumných studií (popř. diplomových a doktorských projektů pod jejich supervizí) zpracovat doplňující data.

Metodu lze jednoznačně doporučit pro využití v poradenské i klinické praxi při práci s dětskými klienty. Jejím prostřednictvím lze získat diagnosticky cenná data pro diferenciální diagnostiku při stanovování různorodých vývojových poruch, pro sledování vývoje dětí, určení profilu jejich kognitivních funkcí i některých osobnostních charakteristik, vymezení silných a slabých stránek a navržení vhodného dalšího postupu výchovné a vzdělávací práce s dětmi. 


\section{MODEL RECENZE PODLE EFPA PRO POPIS \\ A HODNOCENÍ PSYCHOLOGICKÝCH TESTŮ \\ FORMULÁŘ RECENZE TESTU A POZNÁMKY PRO \\ RECENZENTY ${ }^{1}$}

Toto je lokální úprava dokumentu pro účely publikace v časopise Testfórum.

Originální český překlad je k dispozici na stránkách EFPA

(www.efpa.eu/download/505cd9db4144ecb16174087909c9cd6d).

Původní verzi sestavil a uspořádal Dave Bartram

Doplnili a revidovali Patricia Lindley, Dave Bartram a Natalie Kennedy v dubnu $2004^{2}$

Současná verze 3.42: květen 2005

Český překlad: Tomáš Urbánek

Od uživatelů tohoto dokumentu a jeho obsahu žádá EFPA, aby uznali tento zdroj prostřednictvím následujícího textu:

"Kritéria pro recenzi testu podle EFPA do značné míry vychází z formy a obsahu kritérií pro recenze testů Britské psychologické společnosti (BPS) a kritérií vytvořených Komisí pro testové záležitosti (COTAN) Holandské asociace psychologů (NIP). Dave Bartram a Patricia Lindley původně vyvinuli kritéria BPS a recenzní procedury pro UK Employment Service a později rozšírili jejich používání pro celou BPS. Arne Evers připravil k vydání nizozemský system posuzování kvality testů.

EFPA je vděčná BPS a NIP za svolení použít jejich kritéria jako základ pro vytvoření evropského modelu. EFPA je také vděčná Davu Bartramovi, Arnu Eversovi a Patricii Lindley za jejich prispění $k$ vývoji tohoto modelu. Veškerá intelektuální vlastnická práva původních kritérií podle BPS a NIP jsou nadále uznávána a náleží těmto orgánům."

\footnotetext{
1 Tento dokument byl vytvořen z několika zdrojů, včetně Hodnotícího formuláře pro recenzi testu používaného v BPS (NPAL a Řídící komise pro testové standardy při BPS - Steering Committee on Test Standards), Španělského dotazníku pro hodnocení psychometrických testů (Španělská psychologická asociace) a Systému pro posuzování kvality testu (Komise pro testování Holandské asociace psychologů). Některé části byly adaptovány se svolením z dokumentu: BPS Books Reviews of Level B Assessment Instruments for use in Occupational Assessment, Notes for Reviewers: Version 3.1. December 1998: Copyright (C) NPAL, 1989, 1993, 1998.

2 Současná verze je spojením dvou oddělených dokumentů (Formuláře recenze a Poznámek pro recenzenty). Obsah byl navíc uspořádán a doplněn na základě jeho používání recenzenty online testů v BPS.
} 


\section{Část 1:}

Popis nástroje: Obecné informace a klasifikace

EFPA 3.2 reference

\begin{tabular}{|c|c|c|}
\hline & Recenzent 1: & PhDr. Lenka Krejčová, Ph.D. \\
\hline & Recenzent 2: & Mgr. Miroslav Charvát, Ph.D. \\
\hline & Konzultující editor: & \\
\hline & Vedoucí editor: & Mgr. Hynek Cígler \\
\hline & $\begin{array}{l}\text { Vedoucí editor aktualizace: } \\
\text { (pouze v př́padě aktualizací) }\end{array}$ & \\
\hline & $\begin{array}{l}\text { Editor aktualizace: } \\
\text { (pouze v př́padě aktualizací) }\end{array}$ & \\
\hline & Datum vzniku této recenze: & 11.10 .2013 \\
\hline 1.1 & Název nástroje (lokální verze): & $\begin{array}{l}\text { Inteligenční a vývojová škála pro děti ve } \\
\text { věku } 5 \text { - } 10 \text { let }\end{array}$ \\
\hline & Zkrácená verze názvu testu: & IDS \\
\hline 1.2 & $\begin{array}{l}\text { Původní název testu (pokud je lokální } \\
\text { verze adaptací): }\end{array}$ & $\begin{array}{l}\text { Intelligence and Development Scales; } \\
\text { Intelligenz- und Entwicklungsskalen }\end{array}$ \\
\hline 1.4 & Autoři původního testu: & $\begin{array}{l}\text { Alexander Grob, Christine S. Mexer, } \\
\text { Priska Hagmann-von Arx }\end{array}$ \\
\hline 1.3 & Autoři lokální adaptace: & $\begin{array}{l}\text { Dana Krejčířová, Tomáš Urbánek, Jan } \\
\text { Širůček, Michal Jabůrek }\end{array}$ \\
\hline 1.7 & Lokální distributor/vydavatel testu: & Hogrefe - Testcentrum \\
\hline 1.8 & $\begin{array}{l}\text { Vydavatel původní verze testu (pokud je } \\
\text { jiný než současný distributor/vydavatel): }\end{array}$ & Verlag Hans Huber \\
\hline 1.9.1 & Datum vydání současné revize/vydání: & 2013 \\
\hline 1.9 .2 & $\begin{array}{l}\text { Datum vydání adaptace pro lokální } \\
\text { užívání: }\end{array}$ & 2013 \\
\hline 1.9 .3 & Datum vydání původního testu: & 2009 \\
\hline
\end{tabular}




\section{Obecný popis nástroje}

IDS umožňuje diagnostiku kognitivních funkcí i celkového vývoje dětí vě věku 5-10 let. Východiskem pro vznik IDS byl Inteligenční test Kramerové (KIT). Svým formátem navazuje na tradiční př́ístupy Bineta a Simona. Metoda je pokládána za první integrovanou diagnostickou baterii, která sleduje jak kognitivní vývoj dětí dané věkové kategorie, resp. jejich intelekt, tak jejich celkový vývoj.

IDS obsahuje dvacet jedna subtestů, které jsou rozděleny do dvou klíčových částí. První mapuje kognitivní vývoj a škály v ní zahrnuté jsou: zrakové vnímání, selektivní pozornost, fonologická pamět, vizuálně-prostorová pamět', konstrukční myšlení, pojmové myšlení a sluchová pamět'. Druhá část IDS je označována celkový vývoj a je dále rozdělena do pěti škál, z nichž každá zahrnuje několik subtestů v následující podobě: psychomotorika (subtesty - hrubá motorika, jemná motoriky a vizuomotorika), sociálně-emoční kompetence (subtesty - rozpoznávání emocí, regulace emocí, porozumění sociálním situacím a sociálně-kompetentní jednání), matematika (subtest logicko-matematické myšlení), řeč (subtesty - expresivní řeč, receptivní řeč), výkonová motivace (subtesty - vytrvalost úsilí a radost z výkonu). Česká verze IDS byla rozšířena o dva další subtesty, které jsou zahrnuty do části kognitivní vývoj, ale jsou pojímány jako doplňkové, a proto vloženy až na samotný závěr celého nástroje. Jedná se o subtest infromovanost a subtest verbální konceptualizace. Důvodem zařazení doplňkových subtestů byla dominance neverbálních zkoušek, která byla tímto vyrovnána rozšířením o dvě zkoušky vyžadující verbální schopnosti.

Test lze administrovat pouze individuálně, nebot' využívá množství různorodého materiálu, s nímž proband manipuluje. Celková doba administrace činí cca 90-120 minut.

České normy vznikly na souboru 1461 dětí v uvedené věkové kategorii. Mimo to bylo dalších 340 dětí testováno pouze čtyřmi subtesty ze škály sociálně-emoční kompetence.

IDS lze využít v oblasti vývojvé a pedagogické psychologie, výchovného a rodinného poradenství, dětské klinické psychologie i dětské psychiatrie a pediatrie. Profil jednotlivých funkčních oblastí i celkového vývoje umožňuje včasné zachycení vývojových odchylek a volbu adekvátní intervence. 


\section{Část 2:}

\section{Klasifikace}

\begin{tabular}{|c|c|c|}
\hline 1.10 .1 & Obsahová doména & $\begin{array}{ll} & \text { Školní schopnosti } \\
\bigotimes & \text { Všeobecné schopnosti } \\
\bigotimes & \text { Verbální schopnosti } \\
\bigotimes & \text { Numerické schopnosti } \\
\bigotimes & \text { Prostorové schopnosti } \\
\bigotimes & \text { Neverbální schopnosti } \\
\bigotimes & \text { Rychlost vnímání } \\
\bigotimes & \text { Pamět' } \\
\bigotimes & \text { Manuální zručnost } \\
\square & \text { Osobnost - Rys } \\
\square & \text { Osobnost - Typ } \\
\square & \text { Osobnost - Stav } \\
\square & \text { Kognitivní styly } \\
\bigotimes & \text { Motivace } \\
\square & \text { Hodnoty } \\
\square & \text { Zájmy } \\
\square & \text { Přesvědčení } \\
\square & \text { Poruchy a patologie } \\
\square & \text { Skupinové procesy } \\
\square & \text { Rodina } \\
\square & \text { Organizace, její fungování, agregovaná } \\
& \text { měření, klima atd. } \\
\square & \text { Školní nebo výchovné funkce } \\
\square & \text { Jiné: }\end{array}$ \\
\hline 1.10 .2 & $\begin{array}{l}\text { Zamýšlená(é) nebo hlavní oblast(i) } \\
\text { použití. }\end{array}$ & $\begin{array}{ll}\otimes & \text { Klinická psychologie } \\
\square & \text { Neuropsychologie } \\
\square & \text { Forenzní psychologie } \\
\bigotimes & \text { Psychologie výchovy a vzdělávání } \\
\square & \text { Psychologie práce a personalistika } \\
\square & \text { Poradenství, doporučení, vedení a volba } \\
& \text { povolání } \\
\square & \text { Psychologie zdraví, životní styl a životní } \\
& \text { spokojenost } \\
\square & \text { Sporty a volný čas } \\
\square & \text { Jiné: }\end{array}$ \\
\hline
\end{tabular}




\begin{tabular}{|c|c|c|}
\hline 1.10 .3 & $\begin{array}{l}\text { Zamýšlený způsob použití } \\
\text { (podmínky, za jakých byl nástroj } \\
\text { standardizován a validizován) }\end{array}$ & 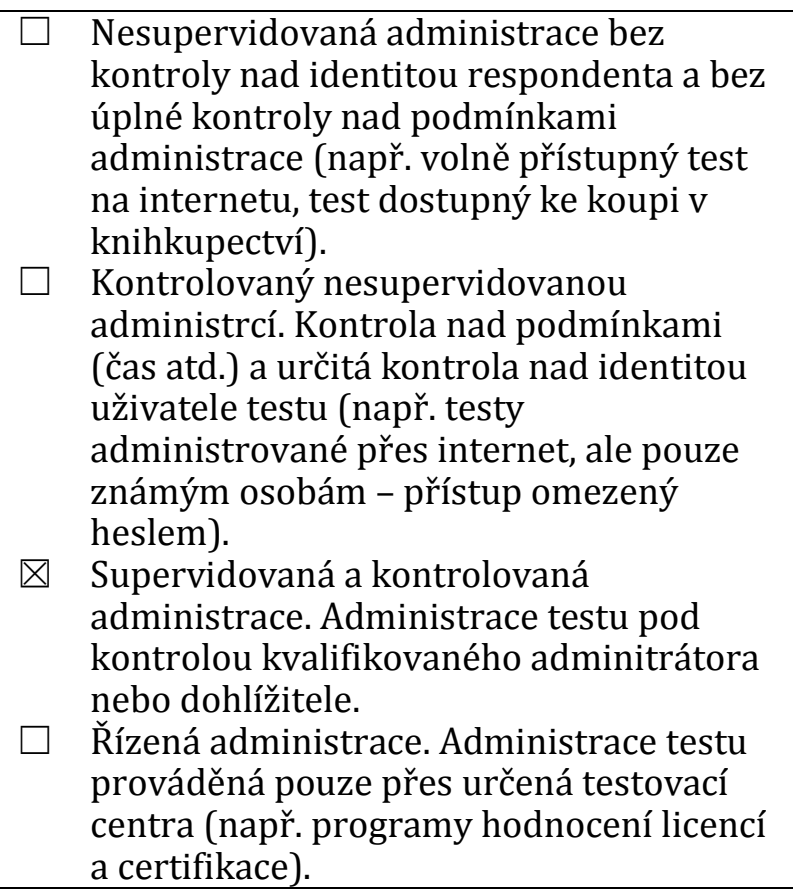 \\
\hline $\begin{array}{l}1.10 .4 \\
\end{array}$ & $\begin{array}{l}\text { Popis populací, pro které je test } \\
\text { určen: }\end{array}$ & Děti obou pohlaví ve věku 5 až 10 let. \\
\hline 1.10 .5 & $\begin{array}{l}\text { Počet škál a krátký popis } \\
\text { proměnné nebo proměnných } \\
\text { měřených nástrojem }\end{array}$ & $\begin{array}{l}\text { Nástroj obsahuje } 21 \text { subtestů shrnutých do } \\
\text { dvanácti škál. } \\
\text { Část kognitivní vývoj: } \\
\text { zrakové vnímání, selektivní pozornost, } \\
\text { fonologická pamět, vizuálně-prostorová pamět', } \\
\text { konstrukční myšlení, pojmové myšlení, } \\
\text { sluchová pamět' } \\
\text { Část celkový vývoj: } \\
\text { psychomotorika (subtesty - hrubá motorika, } \\
\text { jemná motoriky a vizuomotorika), sociálně- } \\
\text { emoční kompetence (subtesty - rozpoznávání } \\
\text { emocí, regulace emocí, porozuméní sociálním } \\
\text { situacím a sciálně-kompetní jednání), } \\
\text { matematika (subtest logicko-matematické } \\
\text { myšlení), řeč (subtesty - expresivní řeč, } \\
\text { receptivní řeč), výkonová motivace (subtesty - } \\
\text { vytrvalost úsilí a radost z výkonu) - tato škála } \\
\text { jako jediná využívá pouze pozorování } \\
\text { administrátora, vychází z reakcí a způsobu } \\
\text { práce probanda po celou dobu vyšetření, } \\
\text { Doplňkové subtesty: } \\
\text { informovanost, verbální konceptualizace }\end{array}$ \\
\hline
\end{tabular}




\begin{tabular}{|c|c|c|}
\hline 1.11 & Formát položek & $\begin{array}{ll} & \text { Otevřený } \\
\square & \text { Mnohonásobná volba, alternativy na stejné } \\
\text { škále } \\
\square \text { Bipolární adjektiva } \\
\square & \text { Likertovy ratingy (škály) } \\
\square & \text { Nucená volba, alternativy na smíšených } \\
\text { škálách (ipsativní) - vysvětlení viz } \\
\text { Poznámky } \\
\square \quad \text { Mnohonásobná volba, alternativy na } \\
\text { smíšených škálách (ipsativní) - vysvětlení } \\
\text { viz Poznámky } \\
\square \text { Sady párủ adjektiv (sémantický } \\
\text { diferenciál), smíšené škály (ipsativní) } \\
\square \quad \text { Jiné: }\end{array}$ \\
\hline 1.12 & Počet položek testu: & 234 \\
\hline 1.13 & Způsob(y) administrace: & $\begin{array}{ll}\otimes & \text { Interaktivní individuální administrace } \\
\square & \text { Supervidovaná skupinová administrace } \\
\square & \text { Počítačová lokálně nainstalovaná aplikace } \\
& \text { - pod supervizí/dohledem } \\
\square & \text { Počítačová aplikace na webu - pod } \\
\text { supervizí/dohledem } \\
\square \quad \text { Počítačová lokálně nainstalovaná aplikace } \\
\text { - bez supervise/testování sebe } \\
\square \quad \text { Počítačová aplikace na webu - bez } \\
\text { supervize/testování sebe } \\
\square \quad \text { Jiné: }\end{array}$ \\
\hline 1.14 & Způsob odpovídání: & $\begin{array}{ll}\bigotimes & \text { Ústní rozhovor } \\
\bigotimes & \text { Papír a tužka } \\
\bigotimes & \text { Manuální operace } \\
\square & \text { Na počítači } \\
\square & \text { Jiné: }\end{array}$ \\
\hline
\end{tabular}




\begin{tabular}{|c|c|c|c|}
\hline 1.15 & 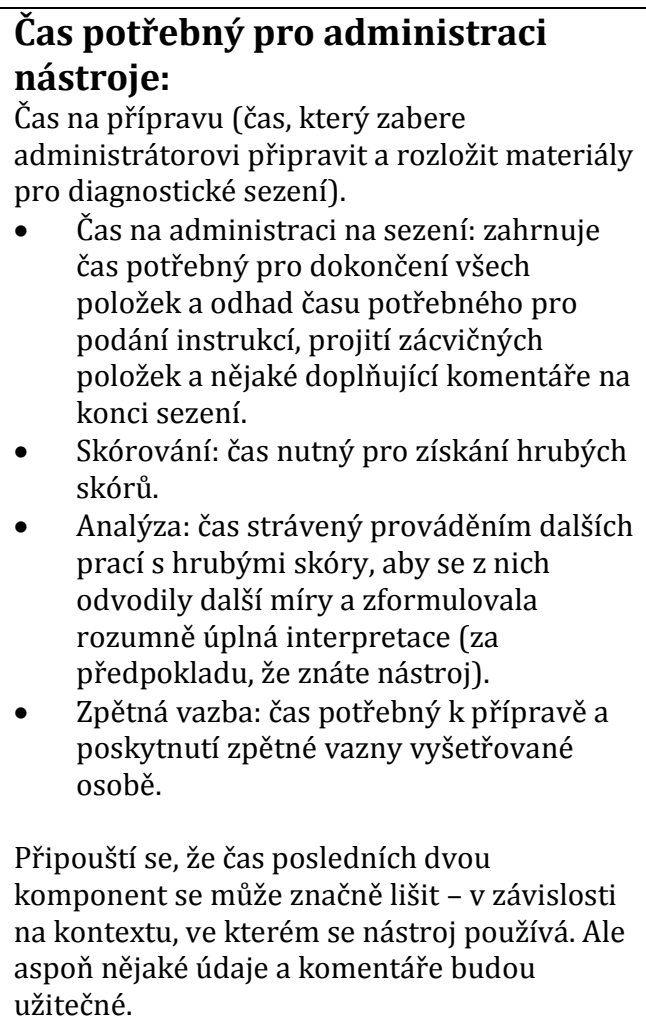 & $\begin{array}{l}\text { Příprava: } \\
\text { Administrace: } \\
\text { Skórování: } \\
\text { Analýza: } \\
\text { Zpětná vazba: }\end{array}$ & $\begin{array}{l}15 \text { minut } \\
90-120 \text { minut } \\
20-30 \text { minut } \\
30-45 \text { minut } \\
60 \text { minut }\end{array}$ \\
\hline 1.16 & $\begin{array}{l}\text { Jsou k dispozici různé formy } \\
\text { nástroje? }\end{array}$ & \multicolumn{2}{|c|}{ Existuje pouze jedna forma nástroje. } \\
\hline
\end{tabular}

\section{Část 3:}

\section{Měření a skórování}

\begin{tabular}{|c|c|c|}
\hline \begin{tabular}{|l|l}
1.17 \\
\end{tabular} & Procedura skórování testu: & 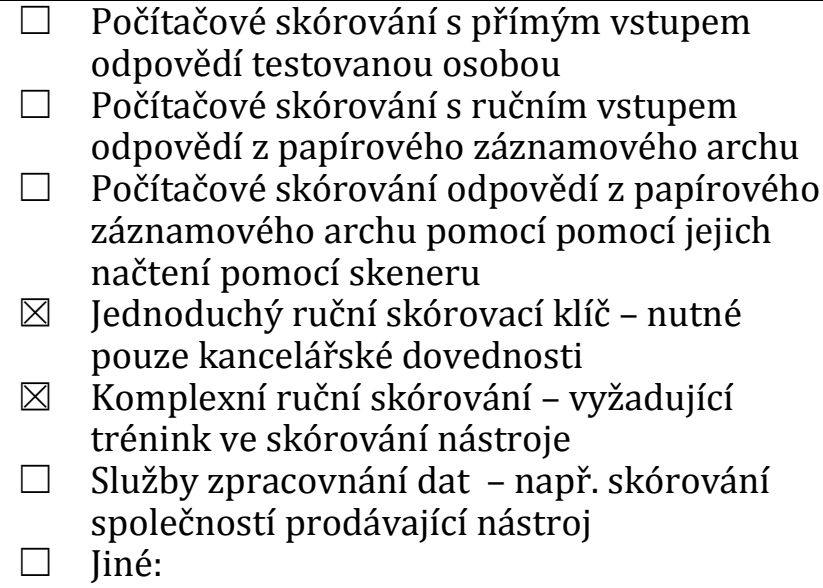 \\
\hline
\end{tabular}




\begin{tabular}{|c|c|c|}
\hline 1.18 & Skóry: & $\begin{array}{l}\text { U subtestů s jednoznačnou možností odpovědí } \\
\text { je stanoveno hodnocení } 1 \text { nebo } 0 \text { bodů. } \\
\text { U subtestů s alternativními možnostmi } \\
\text { odpovědí a u subtestů, u nichž lze pokládat } \\
\text { doplňkové otázky, pokud proband nereaguje } \\
\text { spontánně, je stanoveno hodnocení } 2,1 \text { nebo } 0 \\
\text { bodů, případně } 1,1 / 2 \text { nebo } 0 \text { bodů. U škály } \\
\text { výkonová motivace je možné hodnocení } 1-4 \\
\text { body. } \\
\text { Hrubé skóry jsou následně transformovány na } \\
\text { vážené skóry, které jsou převedeny na IQ skóry } \\
\text { a/nebo percentily. }\end{array}$ \\
\hline 1.19 & $\begin{array}{l}\text { Transformace skóru na standardní } \\
\text { skóry: }\end{array}$ & $\begin{array}{ll}\otimes & \text { Normalizovaná - skóry se získají použitím } \\
\text { normalizační tabulky } \\
\square \quad \text { Nenormalizovaná - skóry se získají lineární } \\
\text { transformací }\end{array}$ \\
\hline 1.20 & Použité škály & 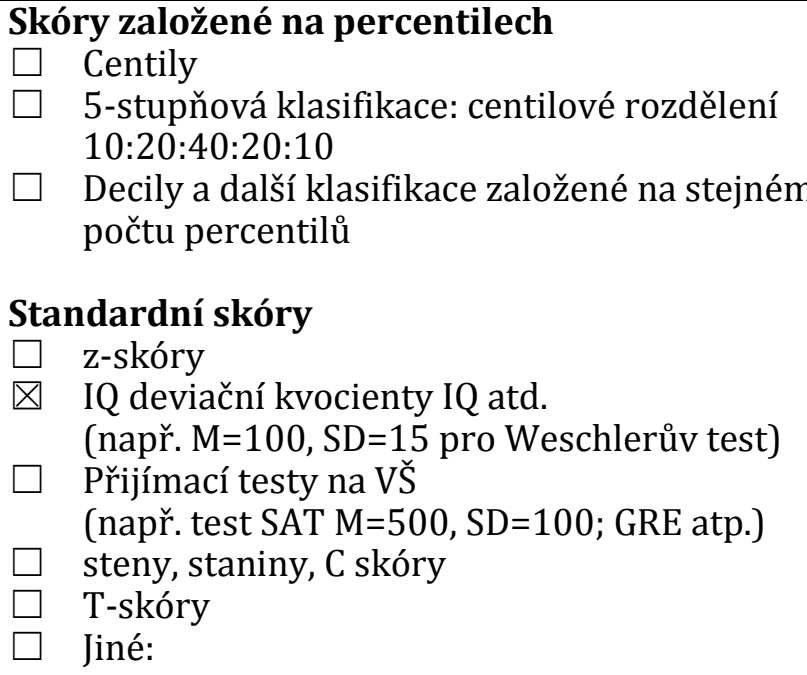 \\
\hline
\end{tabular}

Č́â 4:

Počítačově generované zprávy

Toto je čistě popisné. Hodnocení zpráv bude součástí části recenze nazvané Hodnocení.

\begin{tabular}{|l|l|ll|}
\hline 1.21 & $\begin{array}{l}\text { Jsou počítačově generované zprávy } \mathbf{k} \\
\text { dispozici s nástrojem? }\end{array}$ & $\square$ Ano \\
& $\bigotimes \quad \mathrm{Ne}$ \\
\hline
\end{tabular}




\section{Část 5:}

\section{Nabídka, podmínky a náklady}

Tato část definuje, co vydavatel poskytne, komu, za jakých podmínek a za jaké ceny. Definuje podmínky kladené dodavatelem a týkající se toho, kdo smí a kdo nesmí získat materiál nástroje. Pokud jedna z možností neodpovídá podmínkám nabídky, doplňte popis relevantních podmínek.

\begin{tabular}{|c|c|c|}
\hline 1.23 & $\begin{array}{l}\text { Dokumentace poskytovaná } \\
\text { distributorem jako součást } \\
\text { testového balíku }\end{array}$ & 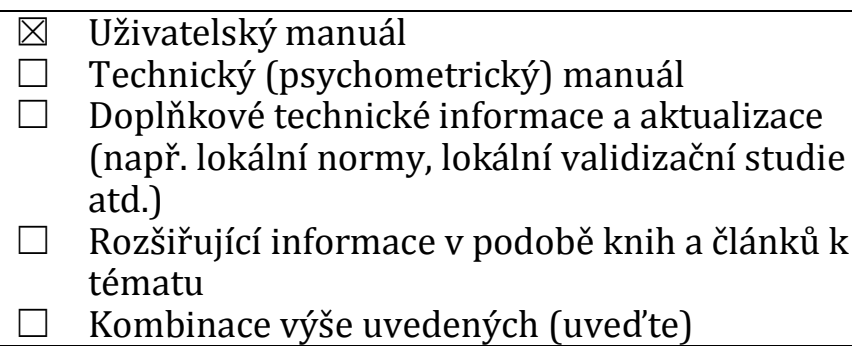 \\
\hline 1.24 & Metody publikace & $\begin{array}{ll} & \text { Papír } \\
\square & \text { PC - Diskety } \\
\square & \text { PC - CD/ROM } \\
\square & \text { Download z internetu } \\
\square & \text { Živý internet (nástroj pracuje v internetovém } \\
\text { prohlížeči) } \\
\square \text { Jiné: }\end{array}$ \\
\hline 1.25 .1 & $\begin{array}{l}\text { Počáteční náklady. } \\
\text { Cena kompletní sady materiálů (všechny manuály a } \\
\text { dalšímaterial nutný } \mathrm{k} \text { aspoñ jedné zkušební } \\
\text { administraci). Kolik uchazeču lze vyšetrovat pomocí } \\
\text { materiálů získaných za pocáteční náklady, kde tyto } \\
\text { náklady zahrnují materially pro opakované vyšetření. }\end{array}$ & $21.000 \mathrm{Kč}$ \\
\hline 1.25 .2 & Opakující se náklady: & 1.700 Kč (25 ks záznamových archů) \\
\hline 1.26 .1 & $\begin{array}{l}\text { Ceny za zprávy generované } \\
\text { softwarem nainstalovaným } \\
\text { uživatelem: }\end{array}$ & - \\
\hline 1.26 .2 & $\begin{array}{l}\text { Ceny za vyhotovení zprávy zaslené } \\
\text { prostřednictvím pošty/faxu: }\end{array}$ & - \\
\hline 1.26 .3 & $\begin{array}{l}\text { Ceny za vyhotovení zprávy zaslené } \\
\text { prostřednictvím internetové služby: }\end{array}$ & - \\
\hline 1.27 & $\begin{array}{l}\text { Ceny za další služby a zpracování } \\
\text { dat: opravy nebo vývoj } \\
\text { automatických zpráv: }\end{array}$ & - \\
\hline
\end{tabular}




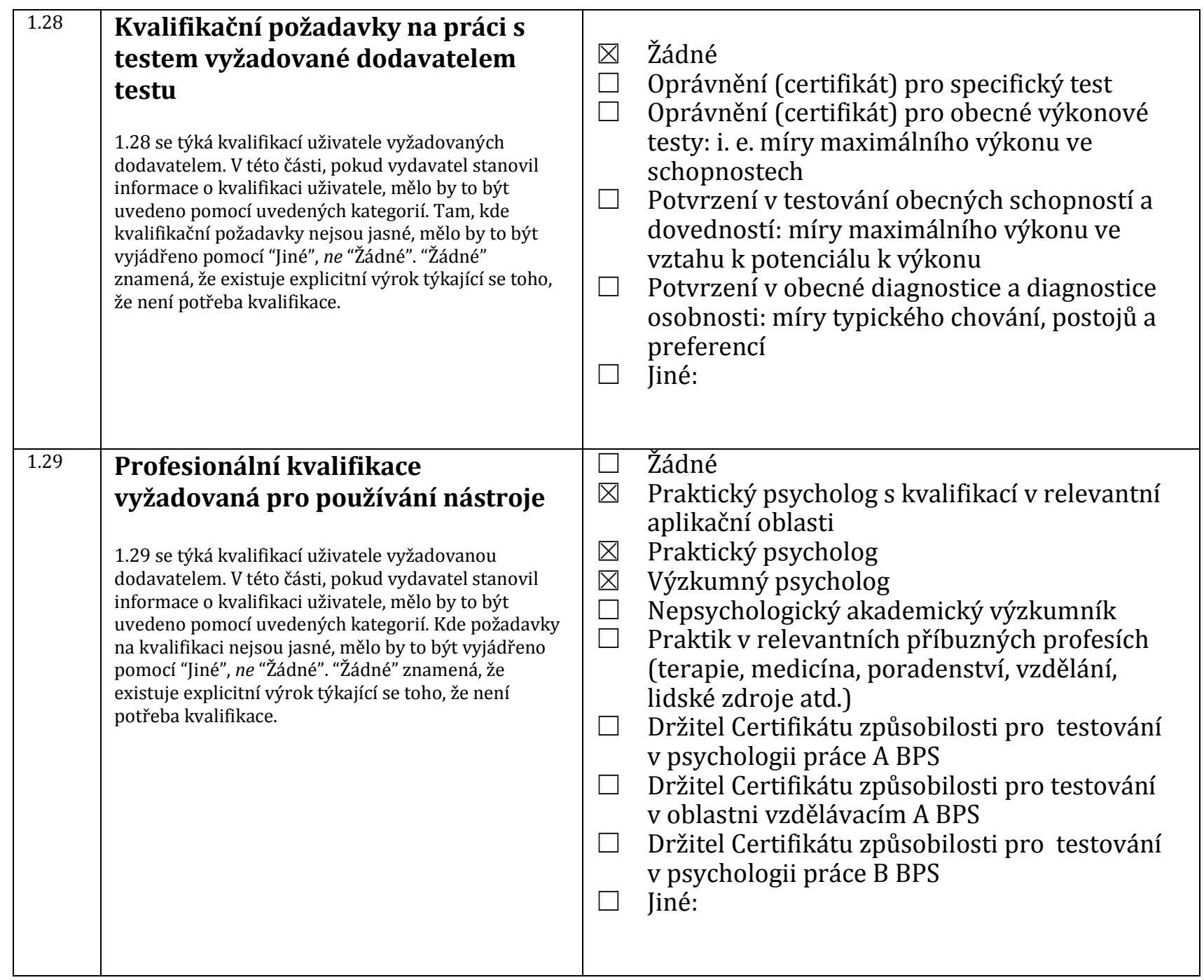


Č́ást 6:

\section{Hodnocení testových materiálů}

\section{Vysvětlení hodnocení}

V následujících částech jsou celková posouzení adekvátnosti informací týkajících se validity, reliability a norem zobrazeny automaticky tučně.

Jakýkoli nástroj s jedním nebo více posouzeními 0 nebo 2 týkajícími se atributů považovaných za kritické pro bezpečné používání nástroje, by neměl být považován za nástroj, který splňuje minimální standardy.

\begin{tabular}{|c|c|c|c|}
\hline $\begin{array}{l}\text { Vstup na posuzovacím } \\
\text { formulářri }\end{array}$ & $\begin{array}{l}\text { Posouzení podle } \\
\text { standardi̊ EFPA }\end{array}$ & $\begin{array}{c}\text { Reprezentace recenze } v \\
\mathrm{UK}\end{array}$ & Vysvětlení \\
\hline [n/a] & [n/a ] & [n/a ] & $\begin{array}{l}\text { Tento atribut není u tohoto } \\
\text { nástroje použitelný }\end{array}$ \\
\hline $\mathbf{0}$ & {$[-]$} & [None ] & $\begin{array}{c}\text { Není možné posoudit jako ne } \\
\text { nebo nedostatek } \\
\text { poskytnutých informací }\end{array}$ \\
\hline 1 & {$[-1]$} & {$\left[\begin{array}{ll}* & ]\end{array}\right.$} & Neadekvátní \\
\hline 2 & & {$\left[\begin{array}{ll}* * & ]\end{array}\right.$} & NYNÍ NEPOUŽÍVÁNO \\
\hline 3 & {$\left[\begin{array}{ll}0 & 0\end{array}\right]$} & {$[* * *]$} & Adekvátní nebo přiměřený \\
\hline 4 & [ 1 ] & {$[* * * *]$} & Dobrý \\
\hline 5 & [ 2 ] & {$[* * * * *]$} & Vynikající \\
\hline & & $\begin{array}{l}\text { [N.r.i.o.r] }{ }^{*} \text { (pouze pro } \\
\text { aktualizace) }\end{array}$ & $\begin{array}{l}\text { Položka nebyla v původní } \\
\text { recenzi posuzována }\end{array}$ \\
\hline
\end{tabular}

V této části má být provedeno více hodnocení různých aspektů nebo atributů dokumentace dodávané s nástrojem (nebo balíkem). Termín „dokumentace“ byl vybrán, aby pokrýval všechny ty materiály dodávané s nástrojem nebo snadno dostupné kvalifikovanému uživateli: např. manual administrátora; technické příručky; brožury s normami; dodatky k manuálu; aktualizace od vydavatelů/dodavatelů atd.

Položky mají být posuzovány n/a nebo 0 až 5 (poloviční rating je přijatelný)

Rating

\begin{tabular}{|c|c|c|}
\hline \multicolumn{2}{|c|}{$\begin{array}{l}\text { Kvalita vysvětlení principů, prezentace a kvalita poskytnuté informace: } \\
\text { (Tento celkový rating se získá použitím posouzení založeného na ratinzích daných pro položky 2.1-2.8) }\end{array}$} & 5 \\
\hline 2.1 & $\begin{array}{l}\text { Celkový rating kvality vysvětlení principů: (Tento celkový rating se získá použitím } \\
\text { posouzení založeného na hodnotách ratingů daných pro položky } 2.1 .1-2.1 .5 \text { ) }\end{array}$ & 5 \\
\hline 2.1 .1 & i) Teoretické základy konstruktů: & 5 \\
\hline 2.1 .2 & ii) Procedura vývoje testu: & 5 \\
\hline 2.1 .3 & iii) Důkladnost analýz položek a model analýzy položek: & 4 \\
\hline 2.1 .4 & iv) Vysvětlení obsahové validity: & 5 \\
\hline 2.1 .5 & v) Souhrn relevantního výzkumu: & 5 \\
\hline 2.2 & $\begin{array}{l}\text { Adekvátnost dokumentace dostupné uživateli (uživatelské a technické } \\
\text { manuály, dodatky týkající se norem atd.): (Tento celkový rating se získá použitím } \\
\text { posouzení založeného na hodnotách ratingů daných pro položky } 2.2 .1-2.2 .6 \text { ) } \\
\text { Pro část } 2.2 \text { jsou stanoveny následující „měřítka“ pro rating „vynikajíci““ (5). Pozornost je zde zaměřena } \\
\text { na kvalitu pokrytí poskytnutého v dokumentaci dostupné kvalifikovaným uživatelüm. Všimněte si, že část } \\
2.2 \text { se týká úplnosti a jasnosti dokumentace dostupné uživateli (uživatelské a technické manually, doadtky } \\
\text { k normám atd.) v pojmech pokrytí a vysvětlení. V pojmech kvality nástroje, jak ji dosvědčuje dokumentace, } \\
\text { jsou rozpracovány oblasti v této části pod čísly: } 2.1,2.3,2.9,2.10 \text { a } 2.11 \text {. }\end{array}$ & 4 \\
\hline
\end{tabular}




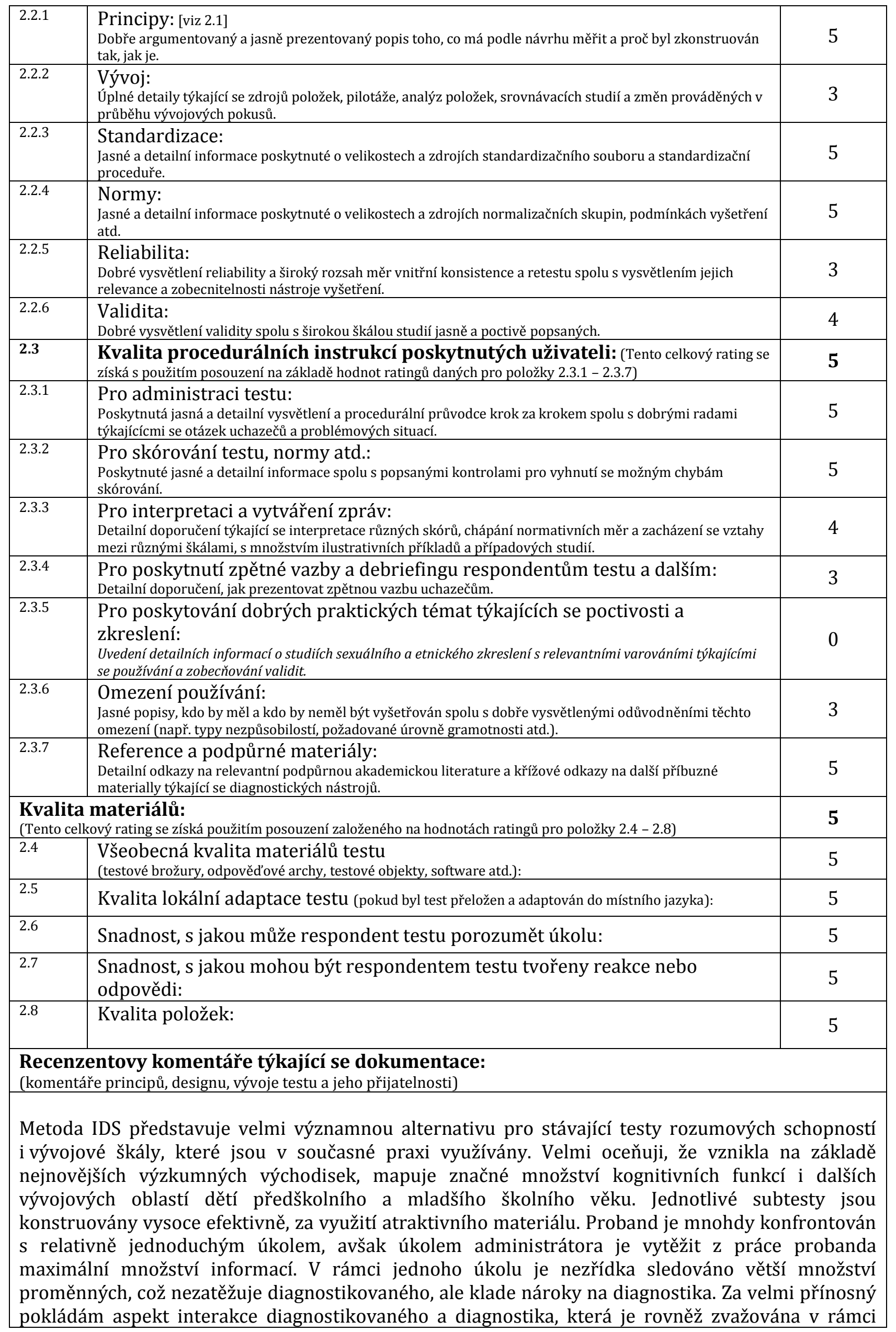


hodnocení projevů probanda. $\mathrm{V}$ úkolech není striktně limitována forma jejich zadávání, ani způsob odpovědí, naopak je vyžadována aktivita administrátora. Vyhodnocení kombinuje zdroje informací z kvantitativního i kvalitativního úhlu pohledu, zvažuje alternativní možnosti odpovědí a umožňuje podporu diagnostikovaného dítěte, pokud čelí obtížím při samostatné práce. Toto vše je následně zohledněno $\mathrm{v}$ rámci vyhodnocení a poskytuje diagnostikovi množství informací pro stanovení aktuálních možností probanda, ale také navržení vhodných intervenčních postupů. Mimo to se jednotlivé subtesty snaží eliminovat vliv školních znalostí dětí a kladou důraz spíše na postupy řešení úkolů, využívání kognitivních operací či sociálně-emočních kompetencí. Takový přístup ke konstrukci testů pokládám za velmi perspektivní a v souladu s moderními psychologickými trendy.

Současně oceňuji využití precizních postupů při vývoji testu - at' už se jedná o vysoké množství relevantní literatury, kterou autoři před samotným vznikem testu nastudovali a jež souvisela jak $\mathrm{s}$ obecnými principy fungování psychických funkcí, které test mapuje, tak jejich vývojovými proměnami, nebo o samotné psychometrické postupy využívané při standardizaci nástroje. Toto platí nejen pro původní německou verzi testu, ale také pro její českou adaptaci, která byla provedena velmi komplexně, za využití obsáhlého standardizačního souboru. Doplňkové subtesty vytvořené pro českou verzi pokládám za zdařilé rozšriření metody, jejímž prostřednictvím diagnostický nástroj ještě více saturuje potřeby psychologické praxe, především pak s ohledem na zmapování edukačních potřeb cílové skupiny.

\section{Část 7:}

\section{Hodnocení norem, reliability a validity}

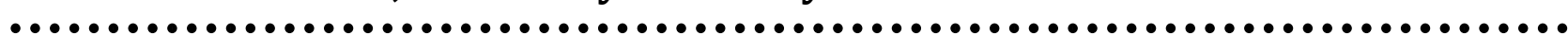

\section{Informace o normách nebo referenční skupině}

\begin{tabular}{|c|c|c|}
\hline 2.9 & Celková adekvátnost: & 5 \\
\hline 2.9 .1 & 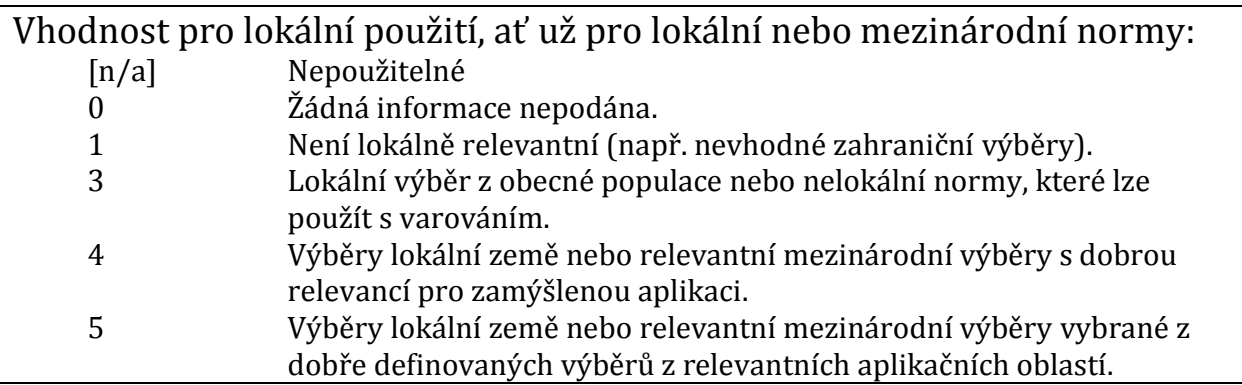 & 5 \\
\hline 2.9 .2 & $\begin{array}{cl}\begin{array}{l}\text { Vhodnost pro zamýšlené aplikace: } \\
{[\mathrm{n} / \mathrm{a}]}\end{array} & \text { Nepoužitelné } \\
0 & \text { Žádná informace nepodána. } \\
1 & \text { Norma nebo normy nejsou adekvátní pro zamýšlené aplikace. } \\
3 & \text { Adekvátní normy pro obecnou populaci a/nebo rozmezí normativních } \\
& \text { tabulek. } \\
5 & \text { Dobré rozmezí normativních tabulek. } \\
& \text { Vynikající rozmezí výběrově relevantních norem vztahujících se k věku } \\
& \text { a pohlaví, s informacemi o dalších rozdílech v rámci skupin (např. } \\
& \text { směs etnických skupin). }\end{array}$ & 4 \\
\hline
\end{tabular}




\begin{tabular}{|c|c|c|c|}
\hline 2.9 .3 & $\begin{array}{l}\text { Velikosti výběrů: } \\
\text { [n/a] } \\
0 \\
1 \\
3 \\
4 \\
5\end{array}$ & $\begin{array}{l}\text { Nepoužitelné } \\
\text { Žádná informace nepodána. } \\
\text { Neadekvátní výběry (např. méně než 150). } \\
\text { Adekvátní výběry (např. 150-300). } \\
\text { Velké výběry (např. 300-1000). } \\
\text { Velmi velké výběry (např. 1000+). }\end{array}$ & 5 \\
\hline 2.9 .4 & $\begin{array}{cc}\text { Procedury použit } \\
\square \\
\bigotimes \\
\square \\
\square\end{array}$ & $\begin{array}{l}\text { té při výběru souboru: } \\
\text { Žádná informace neposkytnuta } \\
\text { Reprezentativní populaci [sumarizujte kritéria] } \\
\text { Nahodilá } \\
\text { Náhodná }\end{array}$ & $\begin{array}{l}\text { Reprezenta- } \\
\text { tivní z hledis- } \\
\text { ka věku, } \\
\text { genderu, sídla }\end{array}$ \\
\hline 2.9 .5 & $\begin{array}{l}\text { Kvalita informací } \\
\text { vlivech věku, rod } \\
\text { [n/a] } \\
0 \\
1 \\
3 \\
4 \\
5\end{array}$ & $\begin{array}{l}\text { í poskytnutých o minoritní/chráněné skupině, rozdílech, } \\
\text { lu atd.: } \\
\text { Nepoužitelné } \\
\text { Žádná informace nepodána. } \\
\text { Neadekvátní informace. } \\
\text { Adekvátní obecné informace s minimální analýzou. } \\
\text { Dobré popisy a analýzy skupin a rozdílů } \\
\text { Vynikající série analýz a diskuse o relevantních tématech vztahujících } \\
\text { se k použití a interpretaci. }\end{array}$ & 3 \\
\hline \multicolumn{4}{|c|}{$\begin{array}{l}\text { 2.9.6 Komentáře recenzentů k normám: Stručná zpráva o normách a jejich historii, včetně informací o doporučeních } \\
\text { učiněných vydavatelem/autorem pro aktualizaci norem obvyklým zpưsobem. }\end{array}$} \\
\hline \multicolumn{4}{|c|}{$\begin{array}{l}\text { Standardizace probíhala velmi komplexně, za využití obsáhlé cílové skupiny. Normy vznikly na } \\
\text { základně vyšetření bezmála dvou tisíc dětí z celé České republiky, byly zastoupeny všechny } \\
\text { relevantní věkové kategorie, složení vzorku z hlediska genderu je vyrovnané. Velmi oceňuji více fází } \\
\text { standardizačního procesu, při nichž došlo k finálním úpravám funkční oblasti sociálně-emoční } \\
\text { kompetence. I v druhé etapě standardizace, se zaměřením na uvedenou funkčí oblast, byl vzorek } \\
\text { cílové skupiny přiměřený a splňoval všechna požadovaná kritéria. }\end{array}$} \\
\hline \multicolumn{4}{|c|}{$\begin{array}{l}\text { Pro další etapy standardizace, je-li plánována průběžná aktualizace norem, bych doporučila věnovat } \\
\text { pozornost také specifickým klinickým populacím. V současné době byla standardizace provedena } \\
\text { pouze na souboru intaktních jedinců. }\end{array}$} \\
\hline
\end{tabular}

\section{Validita}

\begin{tabular}{|c|c|c|}
\hline 2.10 & $\begin{array}{l}\text { Celková adekvátnost: (Tento celkový rating se získá na základě posouzení hodnot ratingů } \\
\text { daných v položkách } 2.10 .1-2.10 .2 .4 \text {. Neprůměrujte pouze čísla, abyste získali celkový rating. } \\
\text { Obvykle bude roven bud' konstruktové validitě nebo validitě vztahující se ke kritériu, podle } \\
\text { toho, která z nich je vyšší.) }\end{array}$ & 4 \\
\hline 2.10 .1 & $\begin{array}{l}\text { Konstruktová validita - celková adekvátnost } \\
\text { (Tento celkový rating se získá na základě posouzení hodnot ratingů daných v položkách } \\
\text { 2.10.1.2 - 2.10.1.6. Neprüměrujte pouze čísla, abyste tento celkový rating získali.) }\end{array}$ & 5 \\
\hline 2.10.1.1 & $\begin{array}{c}\text { Použité plány: (zatrhněte tolik, kolik je jich použitelných) } \\
\square \quad \text { Žádná informace nepodána } \\
\otimes \quad \text { Korelace s dalšími nástroji a výkonovými kritérii } \\
\square \quad \text { Vnitroškálový (korelace položky se zbytkem) } \\
\square \quad \text { Rozdíly mezi skupinami } \\
\square \quad \text { Matice mnoha rysů a mnoha metod (MTMM) } \\
\square \quad \text { Explorační faktorová analýza } \\
\bigotimes \quad \text { Konfirmační faktorová analýza } \\
\square \quad \text { Experimentální plány } \\
\square \quad \text { Jiné: }\end{array}$ & \\
\hline
\end{tabular}




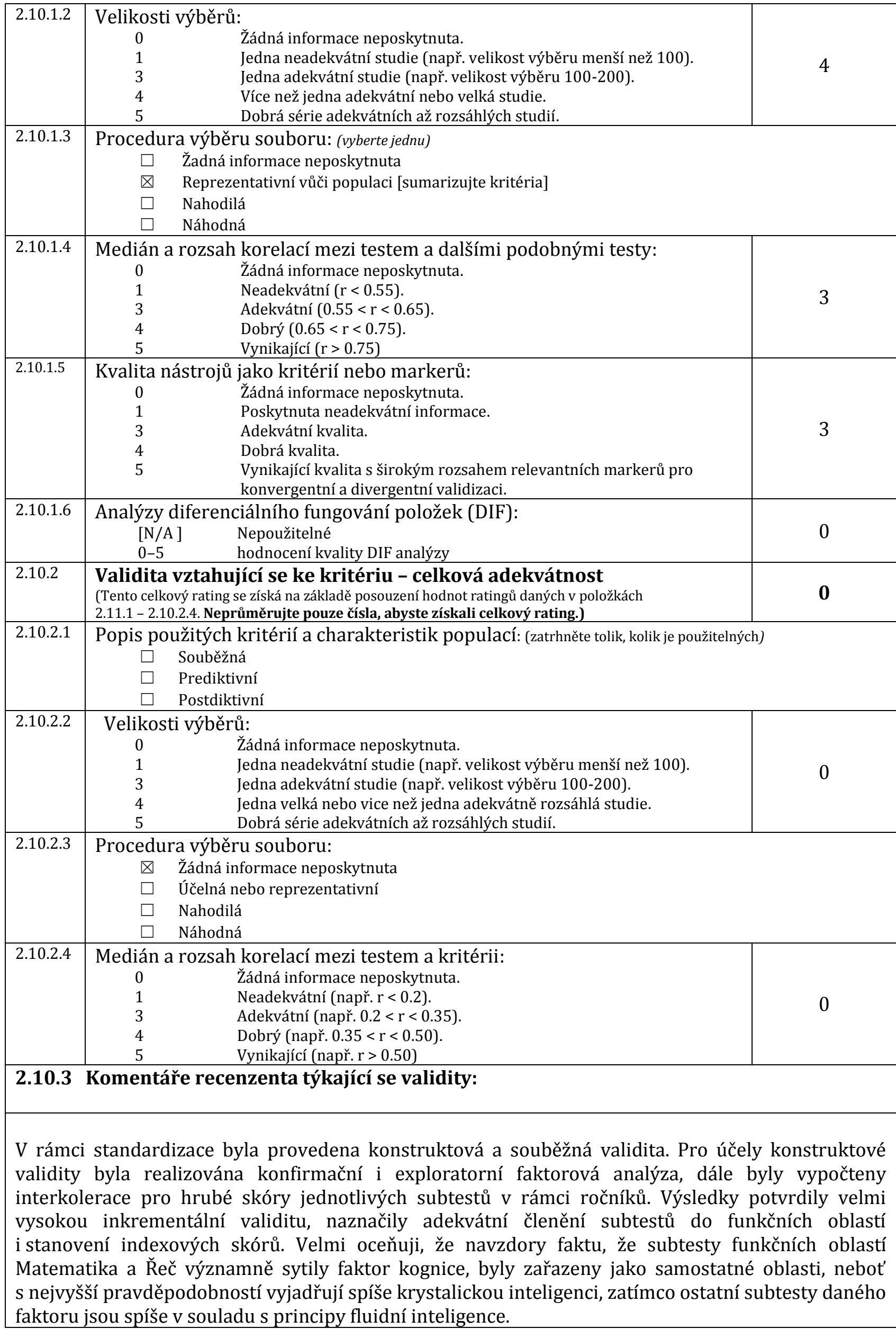


Souběžná validita byla zjišt'ována za využití neverbálního testu inteligence CFT 20 -R u vybrané části standardizačního souboru. Vzhledem $\mathrm{k}$ jeho velikosti se ukázalo, že i velmi nízké korelace vykazovaly signifikanci na hladině významnosti $\mathrm{p}<0,05$ pro funkční oblast Kognice. U dalších funkčních oblastí se výsledky ukazovaly slabší, nebot' tyto části testu zřejmě sledují jiné proměnné než test CFT 20-R.

Vzhledem k omezeným časovým možnostem byly další údaje o standardizaci převzaty z německé verze metody. Veškeré tyto údaje však poukazují na vynikající validitu nástroje.

Za pozornost stojí, že některé výsledky faktorové analýzy na české populaci se ukazují jako stabilnější než v populaci německy hovořící (např. pro subtest Selektivní pozornost).

\section{Reliabilita}

\begin{tabular}{|c|c|c|}
\hline 2.11 & $\begin{array}{l}\text { Celková adekvátnost: } \\
\text { (Tento celkový rating se získá na základě posouzení hodnot ratingů daných v položkách 2.11.1-2.10.2.4. } \\
\text { Neprůměrujte pouze čísla, abyste získali celkový rating.) }\end{array}$ & 3 \\
\hline 2.11.1. & $\begin{array}{cl}\text { Poskytnutá data týkající se reliability: (vyberte jednu možnost) } \\
\square \quad \text { Uveden pouze jeden koeficient reliability } \\
\square \quad \text { Uveden pouze jeden odhad standardní chyby měření } \\
\square \quad \text { Koeficienty reliability pro několik různých skupin } \\
\square \quad \text { Standardní chyba měření uvedená pro několik různých skupin }\end{array}$ & \\
\hline 2.11 .1 & Vnitřní konzistence: & \\
\hline 2.11 .1 .1 & $\begin{array}{cl}\begin{array}{l}\text { Velikost výběru: } \\
0\end{array} & \text { Neposkytnuta žádná informace. } \\
1 & \text { Jedna neadekvátní studie (např. rozsah výběru menší než 100). } \\
3 & \text { Jedna adekvátní studie (např. rozsah výběru 100-200). } \\
4 & \text { Jedna rozsáhlá nebo vice než jedna adekvátně rozsáhlá studie. } \\
5 & \text { Dobrá série adekvátních až rozsáhlých studií. } \\
{[\mathrm{N} / \mathrm{A}]} & \text { Nepoužitelné. }\end{array}$ & 4 \\
\hline 2.11.1.2 & $\begin{array}{ll}\text { Medián koeficientů: } \\
0 & \text { Neposkytnuta žádná informace. } \\
1 & \text { Neadekvátní (např. } \mathrm{r}<0.7 \text { ) } \\
3 & \text { Adekvátní (např. } \mathrm{r}=0.7 \text { až } 0.79 \text { ) } \\
4 & \text { Dobrý (např. } \mathrm{r}=0.8 \text { až } 0.89 \text { ) } \\
5 & \text { Vynikající (např. } r>0.9 \text { ) } \\
{[\mathrm{N} / \mathrm{A}]} & \text { Nepoužitelné. }\end{array}$ & 3 \\
\hline 2.11 .2 & Testová-retestová stabilita: & \\
\hline 2.11 .2 .1 & $\begin{array}{cl}\text { Rozsah výběru: } & \\
0 & \text { Neposkytnuta žádná informace. } \\
1 & \text { Jedna neadekvátní studie (např. rozsah výběru menší než 100). } \\
3 & \text { Jedna adekvátní studie (např. rozsah vy̌běru 100-200). } \\
4 & \text { Jedna rozsáhlá nebo vice než jedna adekvátně rozsáhlá studie. } \\
5 & \text { Dobrá série adekvátních až rozsáhlých studií. } \\
\end{array}$ & 1 \\
\hline 2.11.2.2 & $\begin{array}{cl}\text { Medián koeficientů: } \\
0 & \text { Neposkytnuta žádná informace. } \\
1 & \text { Neadekvátní (např. } \mathrm{r}<0.6 \text { ) } \\
3 & \text { Adekvátní (např. } \mathrm{r}=0.6 \text { až } 0.69 \text { ) } \\
4 & \text { Dobrý (např. } \mathrm{r}=0.7 \text { až } 0.79 \text { ) } \\
5 & \text { Vynikající (např. } \mathrm{r}>0.8 \text { ) } \\
\end{array}$ & 3 \\
\hline 2.11 .3 & Reliabilita jako ekvivalence: & \\
\hline 2.11 .3 .1 & $\begin{array}{cl}\text { Rozsah výběru: } & \\
0 & \text { Neposkytnuta žádná informace. } \\
1 & \text { Jedna neadekvátní studie (např. rozsah výběru menší než 100). } \\
3 & \text { Jedna adekvátní studie (např. rozsah výběru 100-200). } \\
4 & \text { Jedna rozsáhlá nebo vice než jedna adekvátně rozsáhlá studie. } \\
5 & \text { Dobrá série adekvátních až rozsáhlých studií. } \\
{[\mathrm{N} / \mathrm{A}]} & \text { Nepoužitelné. }\end{array}$ & 0 \\
\hline
\end{tabular}




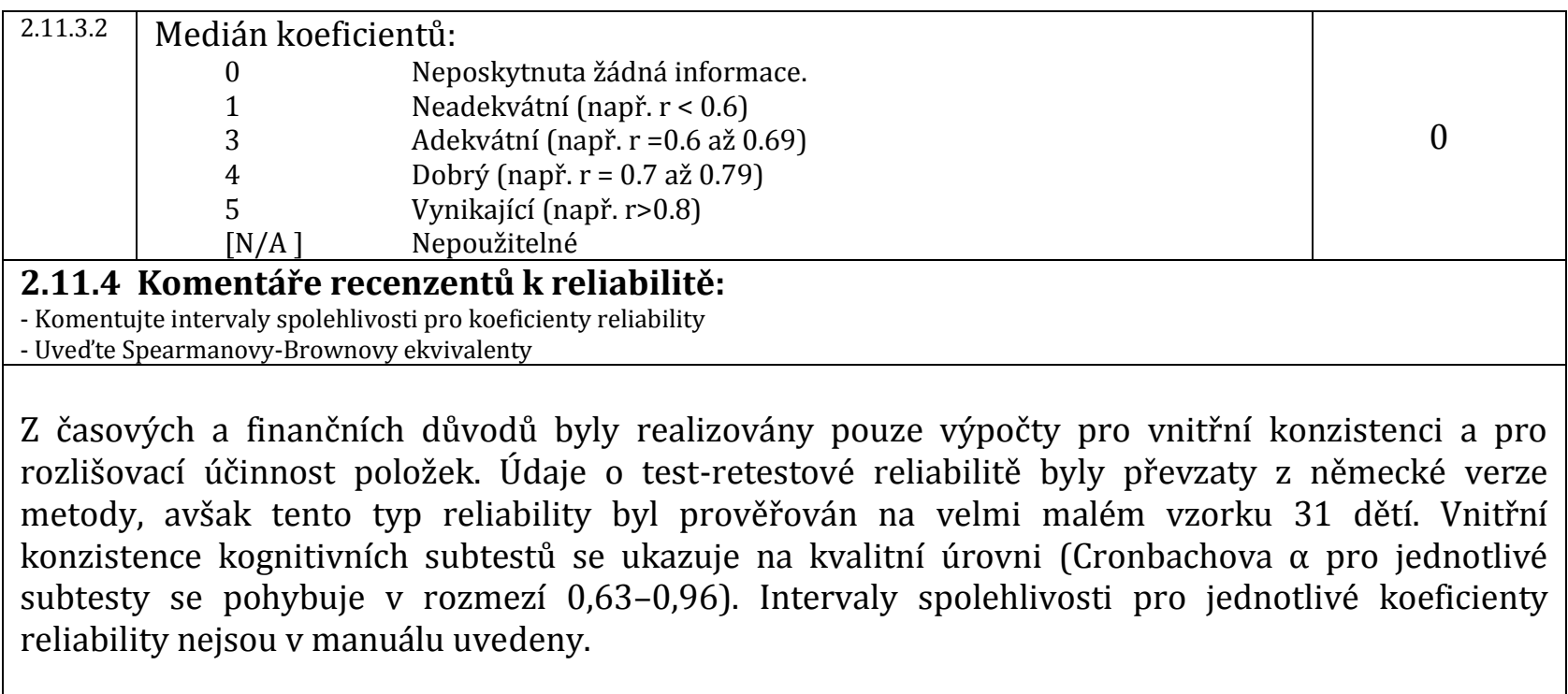

Č́st 9:

Závěrečné hodnocení:

3.0 Hodnotící zpráva testu:

Tato část by měla obsahovat stručné, jasně obhájené posouzení nástroje/produktu. Mělo by popisovat jeho pro a proti a poskytnout určitá obecná doporučení týkající se toho, jak a kdy by se měl používat - spolu s varováními (kde jsou potřebná) týkajícími se případů, kde by se používat neměl.

V současné době je pravděpodobně nejčastěji využívaným nástrojem diagnostiky rozumových schopností u dětí Wechslerova inteligenční škála pro děti (WISC-III), jejíž položky však pozvolna začínají zastarávat, navíc má své limity z hlediska kulturní podmíněnosti a některé subtesty jsou značně determinovány školním vzděláváním diagnostikovaných dětí. Méně rozšířené, přesto relativně časté je užívání metody Woodcock-Johnson International Edition II, která má v zahraničí již novější aktualizace, česká verze vychází ze standardizace v devadesátých letech minulého století. Metoda pokrývá širší spektrum kognitivních funkcí než WISC-III, ale postrádá flexibilitu $v$ administraci a je české odborné veřejnosti hưře dostupná, nebot' je distribuována specifickým způsobem. Před několika lety byl vydán Neverbální inteligenční test SON-R 21/2-7, který rozhodně stojí za pozornost při diagnostice dětí $s$ různými vývojovými deficity a dětí $v$ útlém věku, avšak jeho využití končí na počátku školní docházky. Ve velmi omezené míře je pak využívána Kaufmanova hodnotící baterie pro děti, která je zaměřena na podobnou věkovou skupinu jako IDS a v mnoha ohledech sleduje podobné kognitivní funkce, neexistují pro ni však české normy a neprošla standardizací na české populaci. Ze všeho uvedeného vyplývá, že diagnostická baterie typu IDS na českém trhu jednoznačně schází. Po odborné stránce ji pokládám za unikátní kombinací škál mapujících kognitivní funkce a škál vývojových. Jejich prostřednictvím umožňuje velmi komplexní diagnostiku schopností a dovedností dětí. Za její další přednost pokládám dolní věkovou hranici cílové skupiny. Naopak za určitý nedostatek lze pokládat horní věkovou hranici bezpochyby by obdobný diagnostický nástroj našel své využití i pro vyšší věkové kategorie.

Metoda IDS je využitelná v pedagogicko-psychologické poradenské praxi i v oblasti klinické psychologie, své místo si bezpochyby nalezne i ve výzkumné sféře. Dokáže poskytnout diferenciálně diagnostické údaje pro stanovení vývojových, sociálně-emočních i behaviorálních obtíží, resp. deficitů, stejně jako nabízí na základě zjištěných výsledků návrhy adekvátních forem intervence. 
Oceňuji, že subtesty jsou koncipovány tak, aby byla zajištěna maximální výtěžnost odpovědí probanda. Nezř́́dka musí diagnostik sledovat řadu různých projevů diagnsotikovaného dítěte, což po něm vyžaduje flexibilitu, zkušenosti, dostatečnou kvalifikaci a pečlivý vhled do problematiky, kterou př́íslušný subtest mapuje. Takový př́stup je $v$ souladu $s$ principy moderní diagnostiky, avšak jeho rizikem jsou zvýšené nároky na administrátora, který by dle mého soudu měl být adekvátně proškolen $v$ užívání metody, resp. ve všech teoretických východiscích i kognitivních a vývojových principech, na nichž diagnostický nástroj staví. Na druhou stranu všechny tyto údaje jsou $v$ manuálu nástroje velmi pečlivě rozpracovány. Jako možný zdroj obtíží vnímám stanovené odpovědi v subtestech sytících škálu sociálně-emoční kompetence, $v$ níž mohou být odpovědi ovlivněny kulturními odlišnostmi probadnů, případně některé odpovědi, jež se mohou jevit relevantní, nejsou ve výčtu zahrnuty. $V$ takovém př́padě je nutný kvalifikovaný odhad administrátora. U subtestu selektivní pozornost $v$ části kognitivní vývoj se pak domnívám, že postup práce klade nároky také na další kognitivní procesy (mj. některé složky zrakové percepce a paměti) a nediagnostikuje tak pouze pozornost. Chápu však, že obě zmíněné charakteristiky jsou natolik komplexní a obtížně oddělitelné od dalších poznávacích funkcí, osobnostních či vývojových charakteristik, že stávající forma subtestů je vcelku optimálním řešením.

V neposlední řadě oceňuji zařazení dvou doplňkových subtestů, které vznikly při české lokalizaci metody a obohacují verbální subtesty. Mimo to poskytují údaje o podnětnosti edukačního prostředí probanda.

Domnívám se, že metoda IDS by měla být využívána všemi profesionály, kteří pokládají kvalitní a komplexní diagnostiku za nedílnou součást psychologické práce a současně v ní vidí důležitý zdroj informací, který vede $\mathrm{k}$ volbě další adekvátní práce $s$ klienty, nikoli pouze k mechanickému stanovování diagnóz.

\subsection{Závěry:}

Doporučuji metodu k publikování a distribuci psychologům ve všech relevantních oblastech naší profese. 


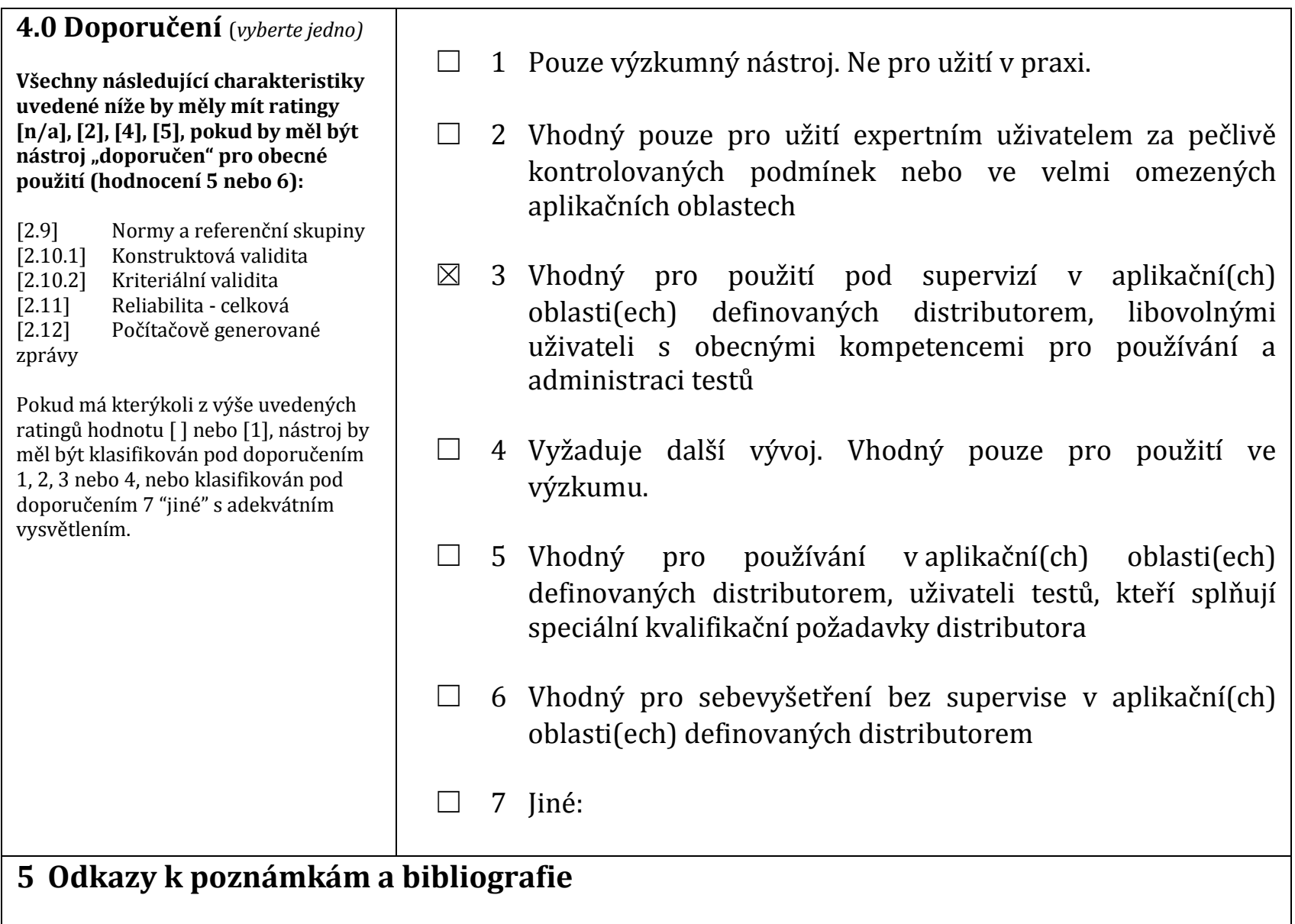

\section{Měřené konstrukty:}

Kognitivní vývoj - zrakové vnímání, selektivní pozornost, fonologická pamět', vizuálně-prostorová pamět', konstrukční myšlení, pojmové myšlení, všeobecná informovanost, verbální konceptualizace.

Celkový vývoj - psychomotorika, sociálně-emoční kompetence, matematika, řeč, výkonová motivace. 